Research Article

Animal Genetics

\title{
Chromosomes of Asian cyprinid fishes: Variable karyotype patterns and evolutionary trends in the genus Osteochilus (Cyprinidae, Labeoninae, "Osteochilini”)
}

Pasakorn Saenjundaeng ${ }^{1}$, Weerayuth Supiwong ${ }^{1}$, Francisco M. C. Sassi ${ }^{2}$, Luiz A. C. Bertollo ${ }^{2}$, Petr Rab ${ }^{3}$, Rafael Kretschmer ${ }^{4}$ (D), Alongklod Tanomtong ${ }^{5}$, Chatmongkon Suwannapoom ${ }^{6}$, Montri Reungsing ${ }^{7}$ and Marcelo de Bello Cioffi ${ }^{2}$ (i)

${ }^{1}$ Faculty of Interdisciplinary Studies, Khon Kaen University, Nong Khai Campus, Nong Khai 43000, Thailand.

${ }^{2}$ Universidade Federal de São Carlos, Departamento de Genética e Evolução, São Carlos, SP, Brazil.

${ }^{3}$ Czech Academy of Sciences, Institute of Animal Physiology and Genetics, Laboratory of Fish Genetics,

Rumburská 89, Libechov 277 21, Czech Republic.

${ }^{4}$ Universidade Federal do Rio Grande do Sul, Programa de Pós-Graduação em Genética

e Biologia Molecular, Porto Alegre, RS, Brazil.

${ }^{5}$ KhonKaen University, Faculty of Science, Department of Biology, Muang, KhonKaen 40002, Thailand.

${ }^{6}$ University of Phayao, School of Agriculture and Natural Resources, Department of Fishery, Muang,

Phayao 56000, Thailand.

${ }^{7}$ Rajamangala University of Technology Tawan-ok, Faculty of Science and Technology,

Department of Biotechnology, Siracha, Chonburi 20110, Thailand.

\begin{abstract}
The Cyprinidae family is a highly diversified but demonstrably monophyletic lineage of cypriniform fishes. Among them, the genus Osteochilus contains 35 recognized valid species distributed from India, throughout Myanmar, Laos, Thailand, Malaysia, Indonesian archipelago to southern China. In this study, karyotypes and other chromosomal characteristics of five Osteochilus species occurring in Thailand, namely O. lini, O. melanopleura, O. microcephalus, $O$. vittatus and $O$. waandersii were examined using conventional and molecular cytogenetic protocols. Our results showed they possessed diploid chromosome number $(2 n)$ invariably $2 n=50$, but the ratio of uni- and bi-armed chromosomes was highly variable among their karyotypes, indicating extensive chromosomal rearrangements. Only one chromosome pair bearing 5 S rDNA sites occurred in most species, except O. melanopleura, where two sites were detected. In contrast, only one chromosomal pair bearing 18S rDNA sites were observed among their karyotypes, but in different positions. These cytogenetic patterns indicated that the cytogenomic divergence patterns of these Osteochilus species were largely corresponding to the inferred phylogenetic tree. Similarly, different patterns of the distributions of rDNAs and microsatellites across genomes of examined species as well as their different karyotype structures indicated significant evolutionary differentiation of Osteochilus genomes.
\end{abstract}

Keywords: Fish cytogenetics, karyotype evolution, repetitive DNAs, Thai ichthyofauna.

Received: June 16, 2020; Accepted: September 29, 2020.

\section{Introduction}

The Cyprinidae family (sensu Tan and Ambruster, 2018), i.e. sensu stricto, is now restricted to phylogenetically and taxonomically highly diversified but a demonstrably monophyletic lineage of cypriniform fishes (Yang et al., 2015) which itself encompasses eleven intra-clade monophyletic lineages taxonomically recently recognized as subfamilies by Tan and Ambruster (2018). One of these lineages, Labeoninae, was demonstrated as sister basal lineage of all remaining cyprinid subfamilies (Conway, 2011; Yang et al., 2015; Stout et al., 2016). Moreover, the lineage monophyly of labeonine cyprinids was supported

Send correspondence to Marcelo de Bello Cioffi. Universidade Federal de São Carlos, Departamento de Genética e Evolução, Rodovia Washington Luís, km 235, CEP 13565-905, São Carlos, SP, Brazil. E-mail: mbcioffi@ufscar.br. by both morphological and molecular studies (see review by Yang et al., 2012). These authors also identified four monophyletic intra-lineage groups within Labeoninae, taxonomically recognized (Tan and Ambruster, 2018) as tribes Garrini, Labeonini and taxonomically informal "Osteochilini" and "Semilabeonini": Labeonine cyprinids are highly morphologically diversified and include altogether around 50 genera with more than 500 species (Eschmeyer Catalog of Fishes, 2020), "Osteochilini" itself contains eight genera with close to 100 recently recognized species.

The genus Osteochilus (Günther, 1868) contains 35 recognized valid species distributed from India, throughout Myanmar, Laos, Thailand, Malaysia, Indonesian archipelago to southern China (Karnasuta, 1993). Although three major systematic revisions have been performed for this genus (Karnasuta, 1993), just eight species were included in detailed molecular phylogenetic analyses performed by Yang et al. 
(2012). Although the cytogenetic analysis are restricted, up to now, to only three species, the results point for a quite large karyotype differentiation inside Osteochilus (Table 1).

Cypriniform cytotaxonomy documents a great $2 \mathrm{n}$ variation, ranging from 42 in Acheilognathus gracilis (Acheilognathidae) (Hong and Zhou, 1985) to 446 in Diptychus dipogon (Cyprinidae) ( $\mathrm{Yu}$ and $\mathrm{Yu}, 1990)$. However, $2 \mathrm{n}=50$ is the most frequent chromosome number, which represents a basal pattern for the whole group (Wolf et al., 1969; Sola and Gornung, 2001). Moreover, several polyploidization events have taken an important role in $2 \mathrm{n}$ variation for cyprinids and differentiated sex chromosomes seem rare (Buth et al., 1991; Rab and Collares-Pereira, 1995; Yang et al., 2015).

This study aimed to analyze karyotypes and other chromosomal characteristics as revealed by conventional (Giemsa-staining and C-banding) and molecular (rDNA and microsatellite FISH) protocols in five species of the genus Osteocheilus occurring in Thailand, namely $O$. lini, $O$. melanoptera, $O$. microcephalus, $O$. vittatus, and $O$. waandersi together with a brief overlook of cytotaxonomy of "osteochiline" cyprinids. The results added new informative characters useful in comparative genomics at the chromosomal level and highlighted extensive diversity among the analyzed species.

\section{Material and Methods}

\section{Individuals, mitotic chromosome preparation and C-banding}

Representatives of five Osteochilus species were collected from distinct natural ecosystems of wild regions in Thailand (Figure 1). The numbers and sexes of the individuals under study were presented in Table 2 . The specimens were

Table 1 - Available cytogenetic data for Osteochilus species.

\begin{tabular}{lccc}
\hline Species & $2 \mathrm{n}$ & Karyotype & References \\
\hline Osteochilus hasselti & $2 \mathrm{n}=50$ & $30 \mathrm{~m}+14 \mathrm{sm}+6 \mathrm{st}$ & Magtoon and Arai, 1990 \\
O. vittatus & $2 \mathrm{n}=50$ & $16 \mathrm{~m}+30 \mathrm{sm}+4 \mathrm{st}$ & Magtoon and Arai, 1990 \\
O. waandersi & $2 \mathrm{n}=50$ & $18 \mathrm{~m}+24 \mathrm{sm}+4 \mathrm{st}+4 \mathrm{a}$ & Magtoonand Arai, 1993 \\
\hline
\end{tabular}

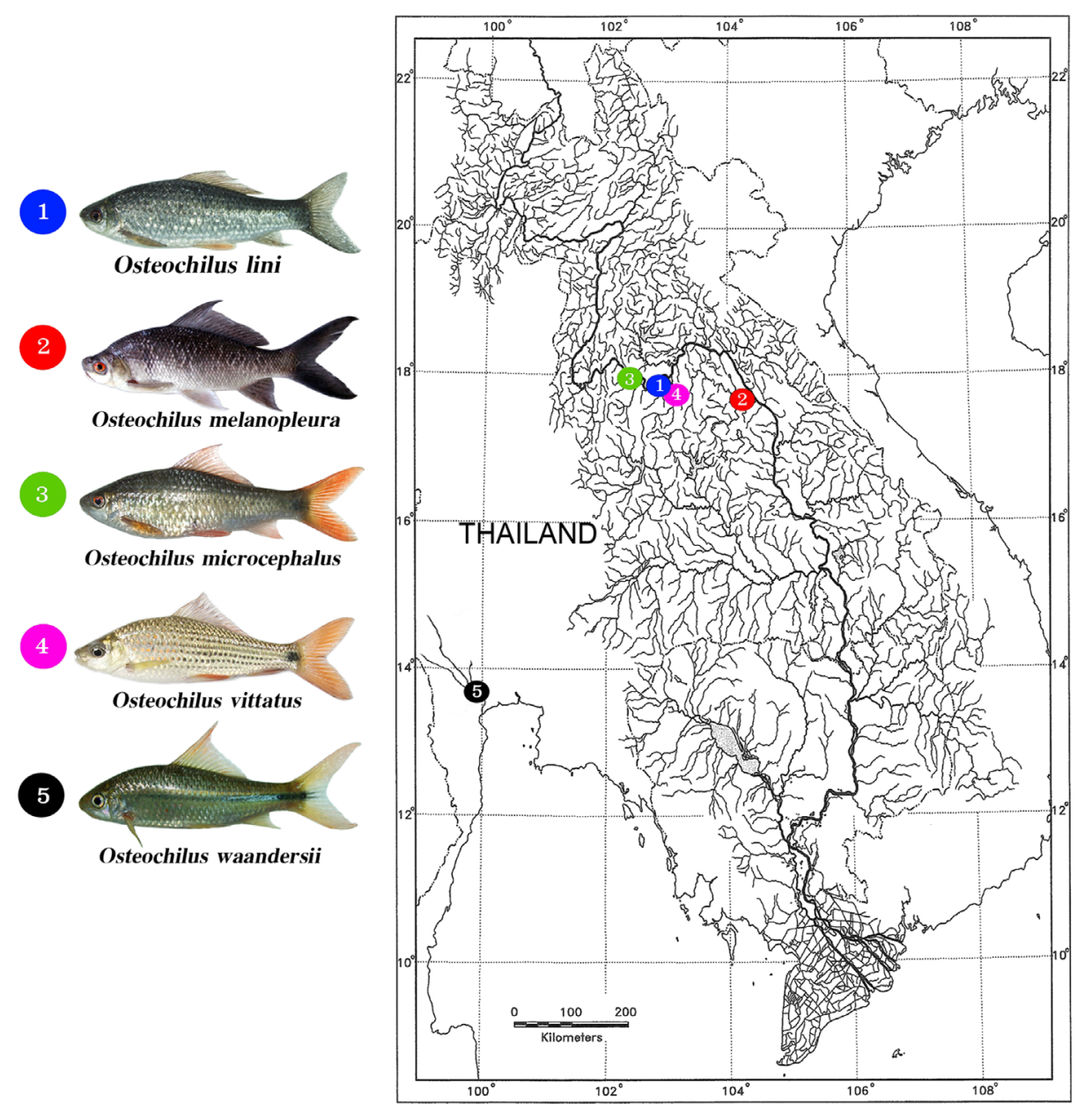

Figure 1 - Thailand map showing the collection sites of the five species studied. 1. Osteochilus lini (blue circles); 2. Osteochilus melanopleura (red circles); 3. Osteochilus microcephalus (green circles); 4. Osteochilus vittatus (pink circles); 5. Osteochilus waandersii (black circles). The maps were created using the following softwares: QGis 3.4.3, Inkscape 0.92 and Photoshop 7.0. 
Table 2 - Species analyzed, collection sites and number of analyzed individuals (n).

\begin{tabular}{|c|c|c|}
\hline Species & Locality & $\mathrm{n}$ \\
\hline 1. Osteochilus lini & $\begin{array}{c}\text { Mekong Basin } \\
17^{\circ} 48^{\prime} 48.7^{\prime} \mathrm{N} 102^{\circ} 43^{\prime} 43.8^{\prime \prime} \mathrm{E} \\
\text { Kom KoSubdistrict, Mueang Nong Khai District, Nong Khai }\end{array}$ & $04+; 05 \hat{\jmath}$ \\
\hline 2. Osteochilus melanopheura & $\begin{array}{c}\text { Mekong Basin } \\
17^{\circ} 39^{\prime} 33.3^{\prime}{ }^{\circ} 104^{\circ} 16 ’ 32.2^{\prime} \mathrm{E} \\
\text { Si SongkhramSubdistrict, Si Songkhram District, Nakhon Phanom }\end{array}$ & 06 우요 \\
\hline 3. Osteochilus microcephalus & $\begin{array}{c}\text { Mekong Basin } \\
17^{\circ} 51^{\prime} \text { '06.5”N } 102^{\circ} 35^{\prime} 15.3^{\prime} \text { E } \\
\text { Kong NangSubdistrict, Tha Bo District, Nong Khai }\end{array}$ & $06+; 07 ð$ \\
\hline 4. Osteochilus vittatus & $\begin{array}{c}\text { Mekong Basin } \\
17^{\circ} 49^{\prime} 06.0^{\prime \prime N} 102^{\circ} 44^{\prime} 09.8^{\prime \prime} \mathrm{E} \\
\text { Kom KoSubdistrict, Mueang Nong Khai District, Nong Khai }\end{array}$ & $12+; 10{ }^{\lambda}$ \\
\hline 5. Osteochilus waandersii & $\begin{array}{c}\text { Mae Klong Basin } \\
13^{\circ} 47^{\prime} 20.2^{\prime}{ }^{\circ} \text { 99 51'44.1'E } \\
\text { Nakhon ChumSubdistrict, Ban Pong District, Ratchaburi }\end{array}$ & $04+; 04 ð$ \\
\hline
\end{tabular}

Sites 1 to 5 correspond to the localization of each collection region shown in Figure 1.

deposited in the fish collections of the Cytogenetic Laboratory, Department of Biology, Faculty of Science (KhonKaen University). Mitotic chromosomes were obtained from anterior kidney, by the conventional air-drying method (Bertollo et al., 2015). The distribution of C-positive heterochromatin blocks was visualized according to Sumner (1972). All the experiments followed ethical protocols, and anesthesia was conducted with clove oil before the sacrifice of the animals. The process was approved by the Animal Ethics Committee of KhonKaen University based on the Ethics of Animal Experimentation of the National Research Council of Thailand AEKKU23/2558.

\section{Fluorescence in situ hybridization (FISH)}

Fluorescence in situ hybridization experiments were performed under high stringency conditions (Yano et al., 2017) to identify both classes of ribosomal DNA and microsatellites $(\mathrm{CA})_{15},(\mathrm{GA})_{15},(\mathrm{GC})_{15},(\mathrm{~A})_{30},(\mathrm{CAC})_{10}$ and $(\mathrm{CGG})_{10}$ sequences. Two tandemly-arrayed DNA sequences isolated from the genome of Hoplias malabaricus, previously cloned into plasmid vectors and propagated in competent cells of Escherichia coli DH5 $\alpha$ (Invitrogen, San Diego, CA, USA), were used. The first probe contained a 5S rDNA repeat copy and included 120 base pairs (bp) of the 5S rRNA transcribing gene and $200 \mathrm{bp}$ of the non-transcribed spacer (NTS) (Martins et al., 2006). The second probe corresponded to the $1400 \mathrm{bp}$ segment of the $18 \mathrm{~S}$ rRNA gene obtained via PCR from the nuclear DNA (Cioffi et al., 2009). Both probes were directly labeled with the Nick-Translation mix kit (Roche, Manheim, Germany). The 5S rDNA was labeled with Spectrum OrangedUTP, and the 18S rDNA was labeled with Spectrum GreendUTP(Vysis, Downers Grove, IL, USA), according to the manufacturer's manual. The microsatellite sequences were directly labeled with Cy-3 during the synthesis, as described by Kubat et al. (2008).

\section{Karyotyping and image processing}

To confirm the $2 \mathrm{n}$ and the results of hybridization experiments, at least 30 metaphase spreads were analyzed per individual. Images were captured with an Axioplan
II microscope (Carl Zeiss Jena GmbH, Germany) with CoolSNAP, and processed using an Image-Pro Plus 4.1 software (Media Cybernetics, Silver Spring, MD, USA). Chromosomes were classified according to their arm ratios as metacentric (m), submetacentric (sm), subtelocentric (st), and acrocentric (a) (Levan et al., 1964).

\section{Results}

All five examined species possessed invariably, for both females and males, $2 \mathrm{n}=50$, but a different composition of their karyotypes: $12 \mathrm{~m}+34 \mathrm{sm}+4 \mathrm{st}$ in Osteochilus lini, $22 \mathrm{~m}+24 \mathrm{sm}+2 \mathrm{st}+2 \mathrm{a}$ in O. melanopleura, $14 \mathrm{~m}+32 \mathrm{sm}+4 \mathrm{st}$ in $O$. microcephalus, $16 \mathrm{~m}+30 \mathrm{sm}+4 \mathrm{st}$ in $O$. vittatus and $16 \mathrm{~m}+26 \mathrm{sm}+8 \mathrm{st}$ in $O$. waandersi (Figure 2). The constitutive heterochromatin was always located at the pericentromeric region of all chromosomes. Additionally, the short (p) arms of some pairs also contained heterochromatic blocks, i.e., the $12^{\text {th }}$ in the karyotype of $O$. lini, $14^{\text {th }}$ of $O$. melanopleura, $11^{\text {th }}$ of $O$. microcephalus, $12^{\text {th }}$ of $O$. vittatus and the $15^{\text {th }}$ of O. waandersi (Figure 2).

FISH experiments documented a single pair bearing $5 \mathrm{~S}$ and 18S rDNA sites in karyotypes of Osteochilus lini (pairs Nos. 08 and 12 respectively), O. microcephalus (Nos. 11 and 03 ), O. vittatus (Nos. 10 and 12) and in O. waandersi (Nos. 22 and 15), while in that of $O$. melanopleura $5 \mathrm{~S}$ rDNA signals were situated on two chromosome pairs (Nos. 12 and 14) and only one pair with the 18S rDNA signal (No 02) (Figure 2).

In general, a spreading pattern was a frequent feature for the microsatellites analyzed. However, some specific features could also be highlighted among species (Figures 3-7). In this sense, $O$. waandersi had small spread (GC) signals in all chromosomes but a strong hybridization pattern in the pericentromeric region of a single pair. For $(\mathrm{A})_{30}, O$. melanopleura showed the pericentromeric region of 46 chromosomes hybridized, while all the other species had scattered signals in all 50 chromosomes. Concerning (CA), while $O$. microcephalus and $O$. waandersi had a scattered distribution in all chromosomes, $O$. lini and $O$. vittatus presented small telomeric signals and $O$. melanopleura had scattered signals except in the centromeric regions. Spreading 


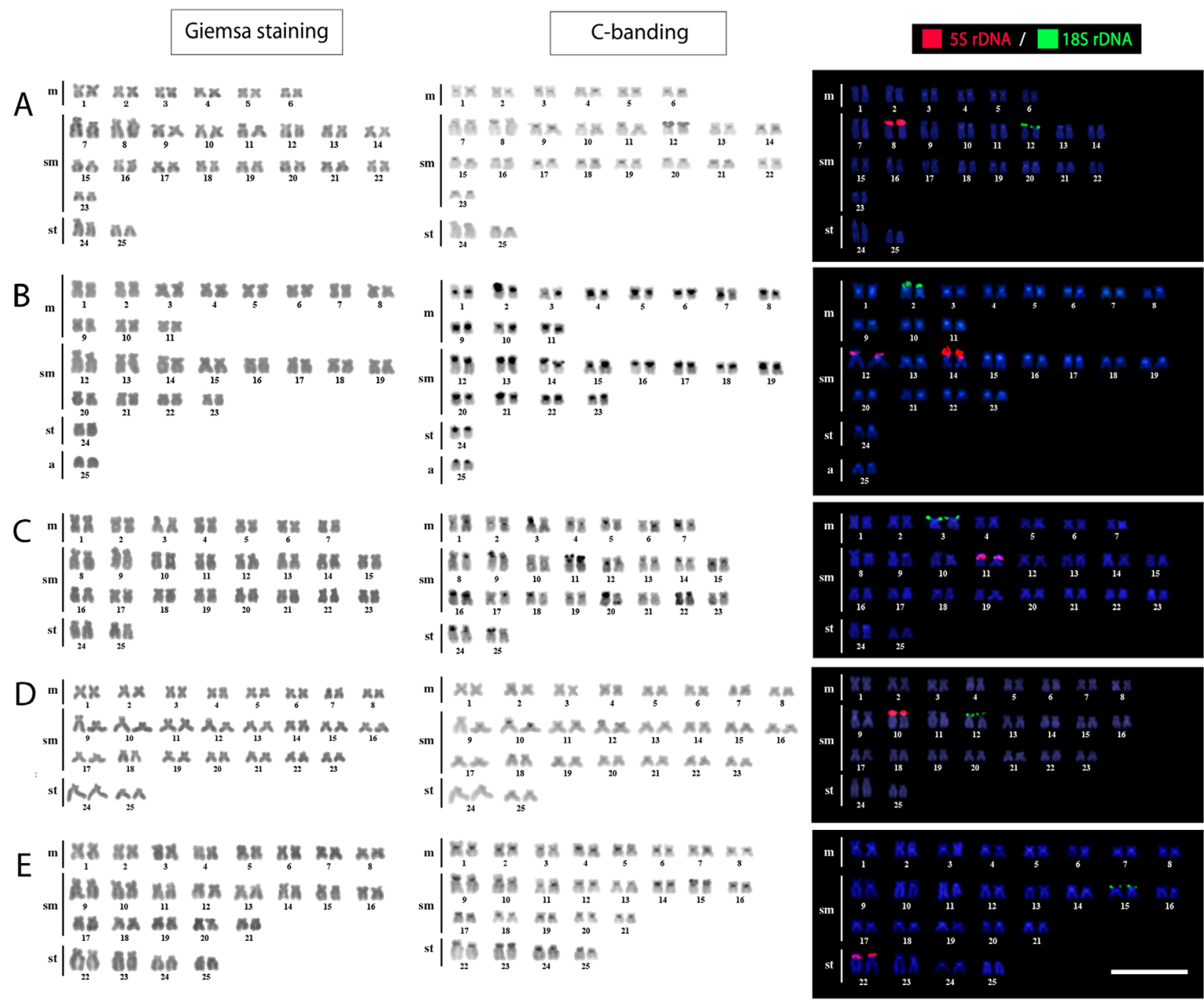

Figure 2 - Karyotypes of the Osteochilus species examined arranged from Giemsa- stained, C-banded chromosomes and chromosomes after FISH with $5 \mathrm{~S}$ (red) and $18 \mathrm{~S}$ (green) rDNA probes. $\mathrm{A}=O$. lini; $\mathrm{B}=$ O. melanopleura; $\mathrm{C}=$ O. microcephalus; $\mathrm{D}=O$. vittatus; $\mathrm{E}=O$. waandersi. Chromosomes were counterstained with DAPI (blue). Scale bar $=5 \mu \mathrm{m}$.

signals were also observed for the $(\mathrm{GA})_{\mathrm{n}},(\mathrm{CAC})_{\mathrm{n}}$, and $(\mathrm{CGG})_{\mathrm{n}}$ probes in all chromosomes of all species. Additionally, O. melanopleura and $O$. vittatus had a strong (CGG) signal in the telomeric region of a single chromosome pair.

\section{Discussion}

“Osteochilini" species possess $2 \mathrm{n}=50$ (Arai, 2011), which is also considered a basal pattern for cypriniform fishes (Chaiyasan et al., 2018). Our results showed that $2 \mathrm{n}=50$ is also a demonstrably conserved pattern for all Osteochilus species karyotyped to date. However, despite the conservative $2 \mathrm{n}$, significant differences in the karyotype structures in all five species examined were observed. Hence, this species also had multiple 5S rDNA sites and a different hybridization pattern for $(\mathrm{A})_{30},(\mathrm{CA})_{15}$ and $(\mathrm{CGG})_{10}$ microsatellites. According to the phylogeny of the Labeonini tribe proposed by Yang and Mayden (2010), Osteochilus was recovered as a monophyletic genus, with three Labiobarbus species forming a sister basal clade (Figure 8). O. melanopleura was recognized as the oldest derived species of the genus and Labiobarbus lineatus possessed 20 acrocentric chromosomes composing its karyotype (Magtoon and Arai, 1990). This fact suggests that the acrocentric pair No. 25 of $O$. melanopleura could be a remnant of the common ancestor between both Osteochilus and Labiobarbus genera. Thus, the karyotype diversification in Osteochilus genus was probably accompanied by a series of structural chromosome rearrangements, with a special role of pericentric inversions or centromere reposition, as indicated by changes in karyotype structure and a constant $2 \mathrm{n}$ (Figure 8).

Many representatives of several fish orders, such as Characiformes, Cypriniformes, Siluriformes, and Gymnotiformes have karyotypes dominated by bi-armed chromosomes (Molina et al., 2014). Our data also demonstrated that Osteochilus species have more bi-armed elements in their karyotypes, suggesting that orthoselection and meiotic drift (White, 1973; Molina et al., 2014) could be strong evolutionary drivers for this group. Noteworthy, the karyotype now reported for $O$. waanders $i$ was different from that reported by Magtoon and Arai (1993).Cypriniform chromosomes have notable small sizes (Sember et al., 2015; Saenjundaeng et al., 2018) and this feature can make it difficult to visualize the correct centromere position (Ráb and Collares-Pereira, 1995; Spoz et al., 2014; 


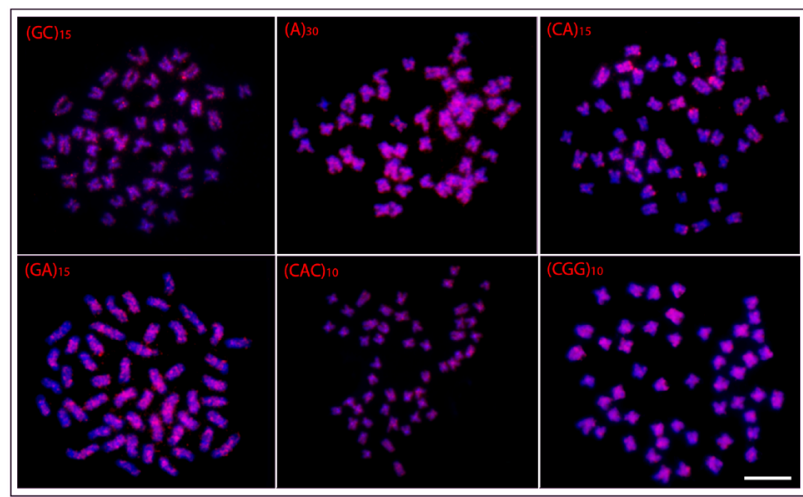

Figure 3 - Hybridization patterns with microsatellites probes (red signals) on metaphase plates of Osteochilus lini. Chromosomes were counterstained with DAPI (blue). Scale bar $=5 \mu \mathrm{m}$.

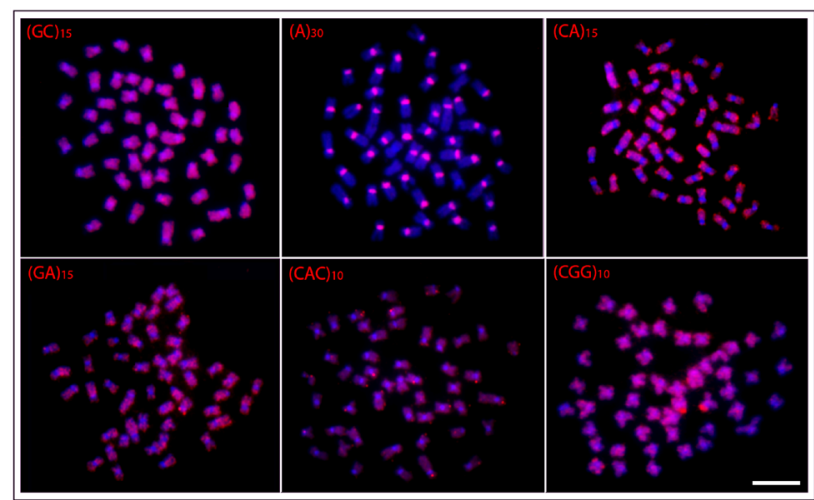

Figure 4 - Hybridization patterns with microsatellites probes (red signals) on metaphase plates of the Osteochilus melanopleura. Chromosomes were counterstained with DAPI (blue). Scale bar $=5 \mu \mathrm{m}$.

Knytl et al., 2018), thus impairing the identification of the chromosomal morphology.

Microsatellite motifs had a preferential accumulation in heterochromatic regions (reviewed in Cioffi and Bertollo, 2012). However, the majority of the microsatellite sequences in Osteochilus showed a scattered pattern on chromosomes, without a specific relation with heterochromatic regions. Nevertheless, the $(\mathrm{A})_{30}$ motif presented a strong accumulation pattern in the pericentromeric regions of $O$. melanopleura, a species in which this same chromosomal region appeared strongly C-banded, i.e., with C-positive heterochromatin. Also, microsatellites are often embedded within rDNA clusters (Piscor and Parise-Maltempi, 2016), which can also explain the strong labeling in the $(\mathrm{CGG})_{\mathrm{n}}$ motifs found in chromosomes of $O$. vittatus and $O$. melanopleura.

Usually, the $18 \mathrm{~S}$ rDNA occupies a terminal position in chromosomes, in contrast to the more frequent interstitial position of the 5S rDNA (Sochorová et al., 2018). All the Osteochilus species under study had both ribosomal classes located in a terminal position in association with heterochromatin, suggesting that these regions were recombination hotspots (Salvadori et al., 1997; Sola et al., 2003; Gornung, 2013). Their terminal position may also facilitate the dispersion of these sequences to other

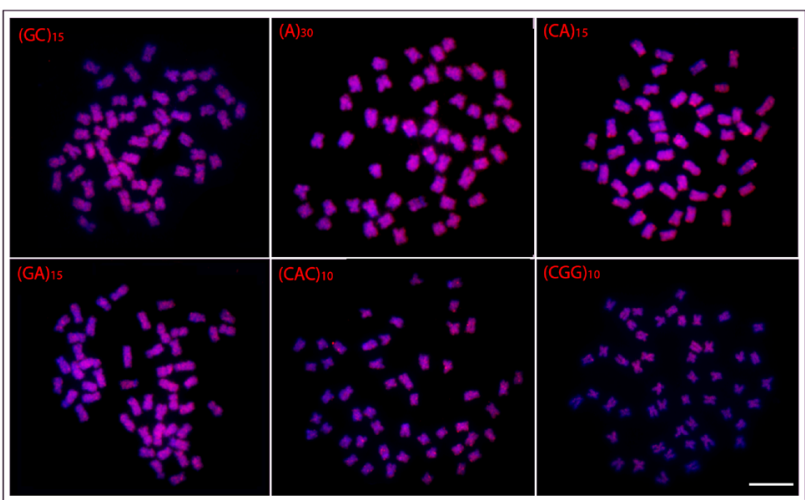

Figure 5 - Hybridization patterns with microsatellites probes (red signals) on metaphase plates of the Osteochilus microcephalus. Chromosomes were counterstained with DAPI (blue). Scale bar $=5 \mu \mathrm{m}$.

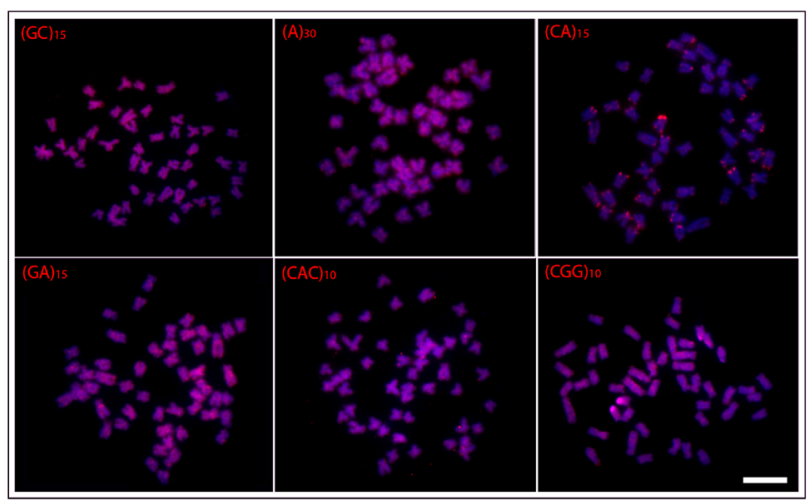

Figure 6 - Hybridization patterns with microsatellites probes (red signals) on metaphase plates of the Osteochilus vittatus. Chromosomes were counterstained with DAPI (blue). Scale bar $=5 \mu \mathrm{m}$.

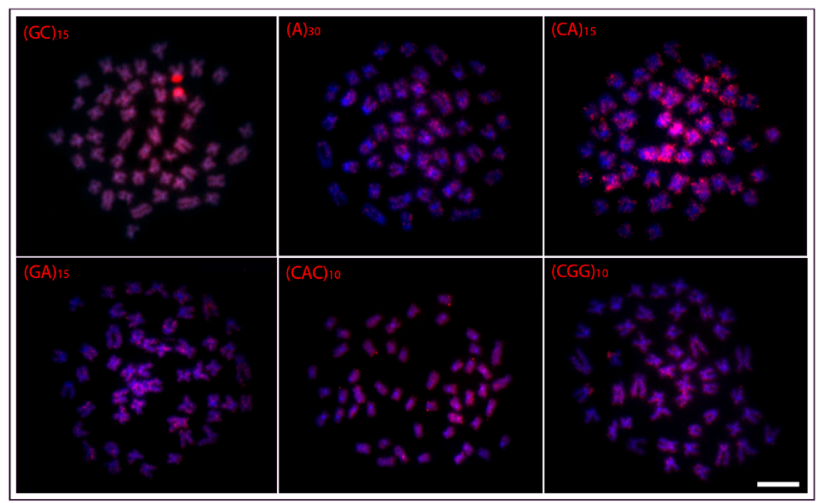

Figure 7-Hybridization patterns with microsatellites probes (red signals) on metaphase plates of the Osteochilus waandersii. Chromosomes were counterstained with DAPI (blue). Scale bar $=5 \mu \mathrm{m}$.

chromosomes, according to Rabl's model, since higher recombination rates were found near the telomeric region (reviewed in Foster and Bridger, 2005). Besides that, the heterochromatinization of ribosomal loci was suggested to facilitate chromosomal heteromorphisms, by unequal crossing over between homologs and/or amplification of the heterochromatin between sister chromatids (Collares-Pereira 


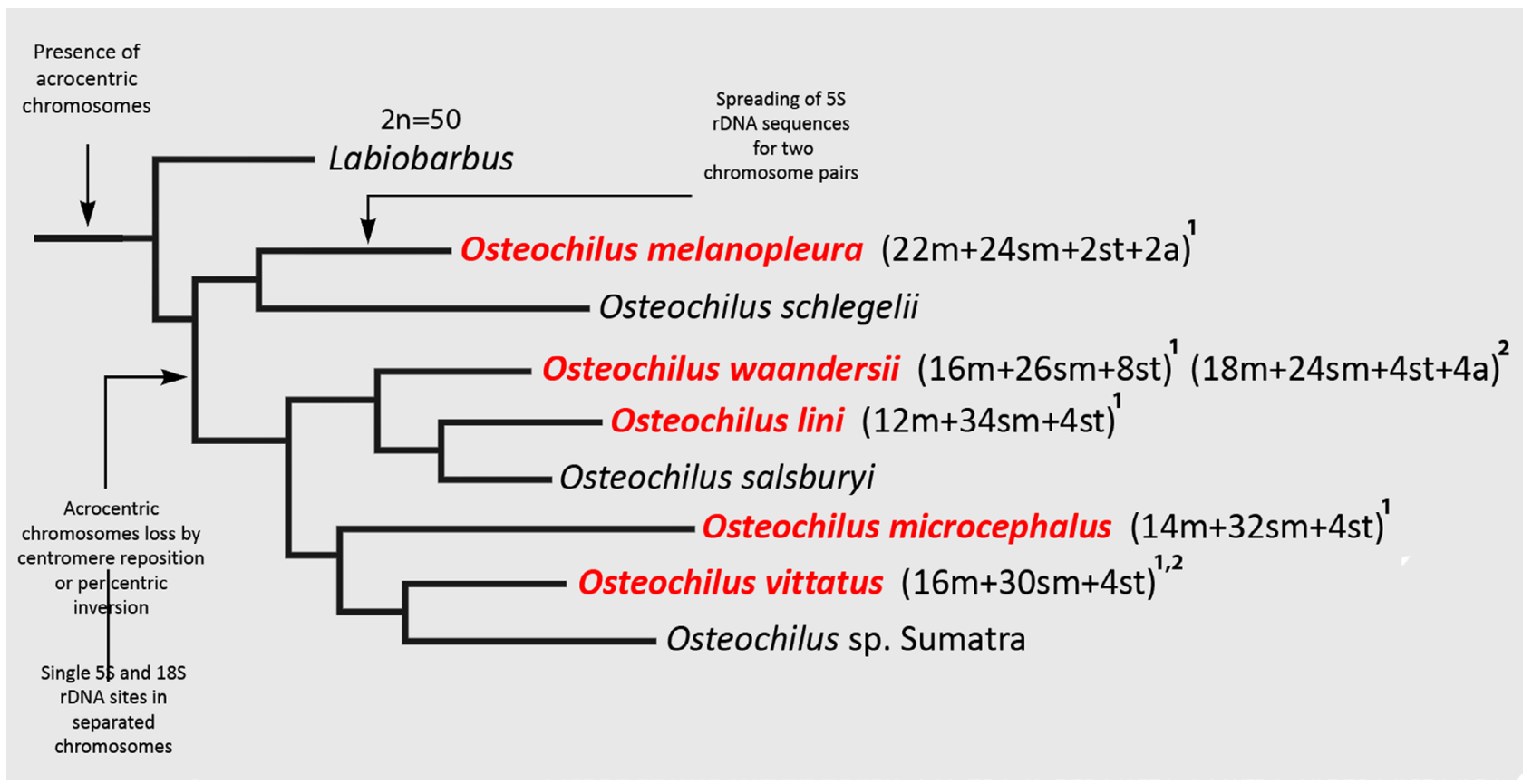

Figure 8 - Adapted phylogenetic tree for the tribe Labeonini, based on the molecular-phylogenetic data generated by Yang et al. (2012) indicating the main chromosomal data obtained in this paper with the superscript 1, and by Magtoon and Arai (1990, 1993) with the superscript 2.

and Ráb, 1999; Sola and Gornung, 2001; Gromicho et al., 2006). The presence of both rDNAs in different chromosomal pairs is a usual condition in fish species (Sochorová et al., 2018), as also observable for cyprinids in our study. Besides, it is noteworthy that $O$. melanopleura was recognized as a basal one in the genus (Karnasuta, 1993; Yang and Mayden, 2010; Figure 8), and this species had two chromosome pairs with $5 \mathrm{~S}$ rDNA sites. In this sense, this could suggest that a single pair bearing such sites in the karyotypes of other Osteochilus species could be a derived pattern. However, this second pair with $5 \mathrm{~S}$ sites in $O$. melanopleura was likely a particular pattern due to spreading events (Figure 8). Ribosomal clusters are characterized by its dynamism promoting significant intragenomic diversification (Gornung, 2013; Rebordinos et al., 2013; Cioffi et al., 2015; Sember et al., 2015; Symonová and Howell, 2018).

A general pattern on Osteochilus karyotypes with a fundamental number (NF) of 100 and a high variation on their karyotype macrostructure can generally be observed. This was somehow expected since Osteochilus is a specious genus, and it is known that the speciation process itself can be the result of high macrostructure karyotypic variation (White, 1973; Lowry and Willis, 2010). However, we cannot disregard the variation found in $O$. melanopleura, the variation that was also probably extended to the sister species $O$. schlegelii, but more studies are required to confirm this assumption.

In conclusion, our data have improved the data about the karyotypes and chromosome characteristics in the genus Osteochilus. Its species presented a conservative $2 \mathrm{n}=50$ and $\mathrm{NF}=100$, but with differentiation of their karyotypes. Altogether these features indicate that chromosomal rearrangements, particularly the structural ones as centromere reposition and pericentric inversions, have taken place a major role during the evolutionary history of this cyprinid genus. The detailed cytogenetic survey indicated that the cytogenomic divergence patterns of these Osteochilus species were largely corresponding to the inferred phylogenetic tree. Also, repetitive DNAs, such as ribosomal and microsatellite ones, showed specificities in their distribution among species, thus being shown as good markers and promoters of specific genomic differentiation inside the genus.

\section{Acknowledgments}

This study was supported by The Faculty of Interdisciplinary Studies, Khon Kaen University, Nong Khai Campus, Research and Technology Transfer Affairs of Khon Kaen University and The Unit of Excellence 2020 on Biodiversity and Natural Resources Management, University of Phayao (UoE63005). MBC was supported by Conselho Nacional de Desenvolvimento Científico e Tecnológico (CNPq) (Proc. Nos. 401962/2016-4 and 302449/2018-3), Fundação de Amparo à Pesquisa do Estado de São Paulo (FAPESP) (Proc. Nos. 2018/22033-1) and CAPES/Alexander von Humboldt (Proc. No. 88881.136128/2017-01). PR was supported by the project EXCELLENCE CZ.02.1.01/0.0/0. 0/15_003/0000460 OP RDE.

\section{Conflict of Interest}

The authors declare that no conflict of interest could be perceived as prejudicial to the impartiality of the reported research.

\section{Author Contributions}

LACB, AT, PR and MBC conceived and the study; PS, WS, FMCS, CS and MR conducted the experiments; PS, WS, FMCS, RK, CS, MR and MBC analyzed the data; PS, WS, FMCS, RK, PR, CS, LACB, MR and MBC wrote the manuscript; authors read and approved the final version. 


\section{References}

Bertollo LAC, Cioffi MB and Moreira-Filho O (2015) Direct chromosome preparation from freshwater teleost fishes. In: Ozouf-Costaz C, Pisano E, Foresti F and Toledo LFA (eds) Fish cytogenetic techniques: Ray-fin fishes and chondrichthyans. 1st edition. RC Press, Boca Raton, pp 21-26.

Buth DG, Dowling TE and Gold JR (1991) Molecular and cytological investigations. In: Nelson JS and Winfield IJ (eds) Cyprinid fishes: Systematics, biology and exploitation. Chapman and Hall, London, pp 83-126.

Chaiyasan P, Supiwong W, Saenjundaeng P, Seetapan K, Pinmongkhonkul S and Tanomtong A (2018) A Report on Classical Cytogenetics of Hihgfin Barb Fish, Cyclocheilichthys armatus (Cypriniformes, Cyprinidae). Cytologia 83:149-154.

Cioffi MB and Bertollo LAC (2012) Chromosomal distribution and evolution of repetitive DNAs in fish. In: Garrido-Ramos MA (ed) Repetitive DNA. Karger Publishers, Basel, pp 197-221.

Cioffi MB, Bertollo LAC, Villa MA, de Oliveira EA, Tanomtong A, Yano CF, Supiwong W and Chaveerach A (2015) Genomic organization of repetitive DNA elements and its implications for the chromosomal evolution of channid fishes (Actinopterygii, Perciformes). PLoS One 10:e0130199.

Cioffi MB, Martins C, Centofante L, Jacobina U and Bertollo LAC (2009) Chromosomal variability among allopatric populations of Erythrinidae fish Hoplias malabaricus: Mapping of three classes of repetitive DNAs. Cytogenet Genome Res 125:132141.

Collares-Pereira MJ and Ráb P (1999) NOR polymorphism in the Iberian species Chondrostoma lusitanicum (Pisces: Cyprinidae) - re-examination by FISH. Genetica 105:301-303.

Conway KW (2011) Osteology of the South Asian Genus Psilorhynchus McClelland, 1839 (Teleostei: Ostariophysi: Psilorhynchidae), with investigation of its phylogenetic relationships within the order Cypriniformes. Zool J Linnean Soc 163:50-154.

Foster HA and Bridger JM (2005) The genome and the nucleus: A marriage made by evolution. Chromosoma 114:212-229.

Gornung E (2013) Twenty years of physical mapping of major ribosomal RNA genes across the teleosts: A review of research. Cytogenet Genome Res 141:90-102.

Gromicho M, Coutanceau JP, Ozouf-Costaz C and Collares-Pereira MJ (2006) Contrast between extensive variation of $28 \mathrm{~S}$ rDNA and stability of 5S rDNA and telomeric repeats in the diploid-polyploid Squalius alburnoides complex and in its maternal ancestor Squalius pyrenaicus (Teleostei, Cyprinidae). Chromosome Res 14:297-306.

Hong Y and Zhou T (1985) Studies on the karyotype and C-banding patterns in Acheilognathus gracilis with a discussion on the evolution of acheilognathid fishes. Acta Gen Sinica 12:143148.

Karnasuta J (1993) Systematic revision of Southeastern Asiatic cyprinid fish genus Osteochilus with a description of two new species and a new subspecies. J Fish Env 19:1-105.

Knytl M, Kalous L, Rylková K, Choleva L, Merilä J and Ráb P(2018) Morphologically indistinguishable hybrid Carassius female with 156 chromosomes: A threat for the threatened crucian carp, C. carassius, L. PLoS One 13:e0190924.

Kubat Z, Hobza R, Vyskot B and Kejnovsky E (2008) Microsatellite accumulation on the $\mathrm{Y}$ chromosome in Silene latifolia. Genome 51:350-356.

Levan A, Fredga K and Sandberg AA (1964) Nomenclature for centromeric position on chromosomes. Hereditas 52:201-220.

Lowry DB and Willis JH (2010) A widespread chromosomal inversion polymorphism contributes to a major life-history transition, local adaptation, and reproductive isolation. PLoS Biol 8:e1000500.
Magtoon W and Arai R (1990) Karyotypes of three cyprinid fishes, Osteochilus hasselti, O. vittatus, and Labiobarbus lineatus, from Thailand. Jpn J Ichthyol 36:483-487.

Magtoon W and Arai R (1993) Karyotypes and distribution of nucleolus organizer regions in cyprinid fishes from Thailand. Jpn J Ichthyol 40:77-85.

Martins C, Ferreira IA, Oliveira C, Foresti F and Galetti PM (2006) A tandemly repetitive centromeric DNA sequence of the fish Hoplias malabaricus (Characiformes: Erythrinidae) is derived from 5S rDNA. Genetica 127:133-141.

Molina WF, Martinez PA, Bertollo LAC and Bidau CJ (2014) Evidence for meiotic drive as an explanation for karyotype changes in fishes. Mar Genom 15:29-34.

Piscor D and Parise-Maltempi PP (2016) Microsatellite organization in the $\mathrm{B}$ chromosome and A chromosome complement in Astyanax (Characiformes, Characidae) species. Cytogenet Genome Res 148:44-51.

Ráb P and Collares-Pereira MJ (1995) Chromosomes of European cyprinid fishes (Cyprinidae, Cypriniformes). Folia Zool Brno 44:193-214.

Rebordinos L, Cross I and Merlo A (2013) High evolutionary dynamism in 5S rDNA of fish: state of the art. Cytogenet Genome Res 141:103-113.

Saenjundaeng P, Kaewmad P, Supiwong W, Pinthong K, Pengseng P and Tanomtong A (2018) Karyotype and characteristics of nucleolar organizer regions in longfin carp, Labiobarbus leptocheilus (Cypriniformes, Cyprinidae). Cytologia 83:265-269.

Salvadori S, Deiana AM, Coluccia E, Cannas R, Cau A and Milia A (1997) Heterochromatin distribution and structure in Gymnothorax unicolor (Anguilliformes, Muraenidae). Ital J Zool 64:125-129.

Sember A, Bohlen J, Šlechtová V, Altmanova M, Symonová R and Rab P (2015) Karyotype differentiation in 19 species of river loach fishes (Nemacheilidae, Teleostei): Extensive variability associated with rDNA and heterochromatin distribution and its phylogenetic and ecological interpretation. BMC Evol Biol 15:251.

Sochorová J, Garcia S, Gálvez F, Symonová R and Kovařík A (2018) Evolutionary trends in animal ribosomal DNA loci: Introduction to a new online database. Chromosoma 127:141-150.

Sola L and Gornung E (2001) Classical and molecular cytogenetics of the zebrafish, Danio rerio (Cyprinidae, Cypriniformes): An overview. Genetica 111:397-412.

Sola L, Rossi AR, Annesi F and Gornung E (2003) Cytogenetic studies in Sparus auratus (Pisces, Perciformes): Molecular organization of $5 \mathrm{~S}$ rDNA and chromosomal mapping of $5 \mathrm{~S}$ and $45 \mathrm{~S}$ ribosomal genes and of telomeric repeats. Hereditas 139:232-236.

Spoz A, Boron A, Porycka K, Karolewska M, Ito D, Abe S, Kirtiklis L and Juchno D (2014) Molecular cytogenetic analysis of the crucian carp, Carassius carassius (Linnaeus, 1758) (Teleostei, Cyprinidae), using chromosome staining and fluorescence in situ hybridisation with rDNA probes. Comp Cytogenet 8:233-248

Stout CC, Tan M, Lemmon AR, Lemmon EM and Armbruster JW (2016) Resolving Cypriniformes relationships using an anchored enrichment approach. BMC Evol Biol 16:1-13.

Sumner AT (1972) A simple technique for demonstrating centromeric heterochromatin. Exp Cell Res 75:304-306.

Symonová R and Howell WM (2018) Vertebrate genome evolution in the light of fish cytogenomics and rDNAomics. Genes (Basel) 9:96.

Tan M and Armbruster JW (2018) Phylogenetic classification of extant genera of fishes of the order Cypriniformes (Teleostei. Ostariophysi). Zootax $a$ 4476:6-39.

White MJD (1973) Animal cytology and evolution. 3rd edition. Cambridge University Press, Cambridge, 468 p. 
Wolf U, Ritter H, Atkin NB and Ohno S (1969) Polyploidization in the fish family Cyprinidae, order Cypriniformes. Humangenetik 7:240-244.

Yang L and Mayden RL (2010) Phylogenetic relationships, subdivision, and biogeography of the cyprinid tribe Labeonini (sensu) (Teleostei: Cypriniformes), with comments on the implications of lips and associated structures in the labeonin classification. Mol Phylogenet Evol 54:254-265.

Yang L, Arunachalam M, Sado T, Levin BA, Golubtsov AS, Freyhof J, Friel JP, Chen WJ, Hirt MV, Manickam R et al. (2012) Molecular phylogeny of the cyprinid tribe Labeonini (Teleostei: Cypriniformes). Mol Phylogenet Evol 65:362-379.

Yang L, Sado T, Hirt MV, Pasco-Viel E, Arunachalam M, Li J, Wang X, Freyhof J, Saitoh K, Simons AM et al. (2015) Phylogeny and polyploidy: Resolving the classification of cyprinine fishes (Teleostei: Cypriniformes). Mol Phylogenet Evol 85:97-116.
Yano CF, Bertollo LAC and Cioffi MB (2017) Fish-FISH: Molecular cytogenetics in fish species. In: Liehr T (ed) Fluorescence In Situ Hybridization (FISH). Springer, Berlin, pp 429-443.

Yu XY and Yu XJ (1990) A schizothoracine fish species, Diptychus dipogon, with a very high number of chromosomes. Chromosome Inform Serv 48:17-18.

\section{Internet resources}

Eschmeyer's Catalog of Fishes, http://researcharchive.calacademy. org/research/ichthyology/catalog/SpeciesByFamily.asp (accessed 12 January 2020).

Associate editor: Maria José de J. Silva

License information: This is an open-access article distributed under the terms of the Creative Commons Attribution License (type CC-BY), which permits unrestricted use distribution and reproduction in any medium, provided the original article is properly cited. 